\title{
Titanasilsesquioxane-Alkylaluminum Catalyst System for Ethylene Polymerization
}

\author{
Akshay Mehta ${ }^{1}$, Gopal Tembe ${ }^{2 *}$, Parimal Parikh ${ }^{3}$, Girish Mehta ${ }^{1}$ \\ ${ }^{1}$ Applied Chemistry Department, S. V. National Institute of Technology, Surat, India \\ ${ }^{2}$ Reliance Technology Group, Reliance Industries Limited, Vadodara Manufacturing Division, Vadodara, India \\ ${ }^{3}$ Chemical Engineering Department, S. V. National Institute of Technology, Surat, India \\ Email: gopal.tembe@ril.com
}

Received August 4, 2012; revised September 8, 2012; accepted September 20, 2012

\begin{abstract}
Homogeneous Ti (IV) complexes covalently anchored to Polyhedral Oligomeric Silsesquioxane (POSS) have been synthesized by the stoichiometric reaction between titanium (IV) alkoxide and (iso-Octyl $)_{7} \mathrm{Si}_{7} \mathrm{O}_{9}(\mathrm{OH})_{3}$. These catalyst precursors formulated as $\left[\mathrm{Ti}(\mathrm{OR})(\text { iso-Octyl })_{7} \mathrm{Si}_{7} \mathrm{O}_{12}\right]$ were characterized by physicochemical and spectroscopic methods. These supported catalysts are found to be active in polymerization of ethylene at high temperatures in presence of ethylaluminum sesquichloride $\left(\mathrm{Et}_{3} \mathrm{Al}_{2} \mathrm{Cl}_{3}, \mathrm{EASC}\right)$ as co-catalyst. The polyethylene obtained is generally linear, crystalline and display low molecular weight distribution. The microstructure of the polymer was analyzed by NMR and FT-IR spectroscopic methods which indicated a chain transfer reaction to aluminum. The unique molecular properties of PE formed has been compared with commercial micronized PE wax which find industrial applications in surface coating and ink formulations. The effect of reaction conditions on catalytic behaviour is described.
\end{abstract}

Keywords: POSS; Titanasilsesquioxane; Polyethylene; Ethylaluminum Sesquichloride; Polymer Microstructure

\section{Introduction}

Numerous catalysts have been developed, studied and commercialized for the production of polyolefins [1-4]. A large fraction of these catalysts, especially the industrially relevant ones, are heterogeneous systems prepared by the deposition of soluble complexes of $\mathrm{Ti}, \mathrm{Zr}$ and $\mathrm{Cr}$ including metallocene precursors on high surface area supports such as silica and alumina [5]. The best choice of support for heterogeneous olefin polymerization catalyst is amorphous silica gel because it has a high surface area, good morphology, fragmentation properties and silanol functionalities to anchor the catalyst [6]. However, due to the heterogeneous nature of the catalysts the catalytic species are difficult to characterize and mechanisms of the catalyzed organic transformations and the nature of the metal-silica interactions remain unclear. This is due to the inherently very complicated atomic structure of the anchored silica surfaces. Improvement of this and alternative immobilization techniques, such as catalyst tethering [7,8] and grafting [9-11], remains therefore a topic of great interest.

The oxophilic alkoxide group has been considered as alternative for the ubiquitous Cp ligands. A few aliphatic and aromatic alkoxides of group (IV) metals have been

${ }^{*}$ Corresponding author. employed for the oligomerization of ethylene in presence of alkylaluminum activators. As indicated in Scheme 1 a majority of these lead to dimers or alpha olefins as the end products [12]. Some silica supported $\mathrm{Ti}(\mathrm{OEt})_{4}$ complexes developed by Phillips in the eighties also showed dimerization activity for ethylene in presence of methyllalumoxane (MAO) co-catalyst [13]. In an earlier study, we had shown that bulky titanium aryloxide complexes were found to be selective towards the formation of linear $\alpha$-olefins from ethylene in combination with ethylaluminum sesquichloride $\left(\mathrm{Et}_{3} \mathrm{Al}_{2} \mathrm{Cl}_{3}, \mathrm{EASC}\right)$ as co-cata lyst [14]. Due to the high tendency of $\beta$-hydride elimination associated with these catalysts preparation of high molecular weight polyethylene for industrial applications poses a challenge [15].

In recent years polyhedral oligomeric silsesquioxanes (POSS) have gained attention for its effective homogeneous mimic for zeolites as well as amorphous and mesoporous silica which contain surface silanol sites. POSS are a class of three dimensional oligomeric organosilicon compounds with cage like framework (ca. $1.5-2.0 \mathrm{~nm}$ ) possessing different degrees of symmetry. Over the last decade or so these materials have evolved as alternative supports to silica surfaces for heterogenizing homogeneous catalysts [16-18]. The most common silsesquioxane systems include the cube-octameric clusters (i.e. $\mathrm{R}_{8} \mathrm{Si}_{8} \mathrm{O}_{12}$ ) and incompletely condensed frameworks such as 


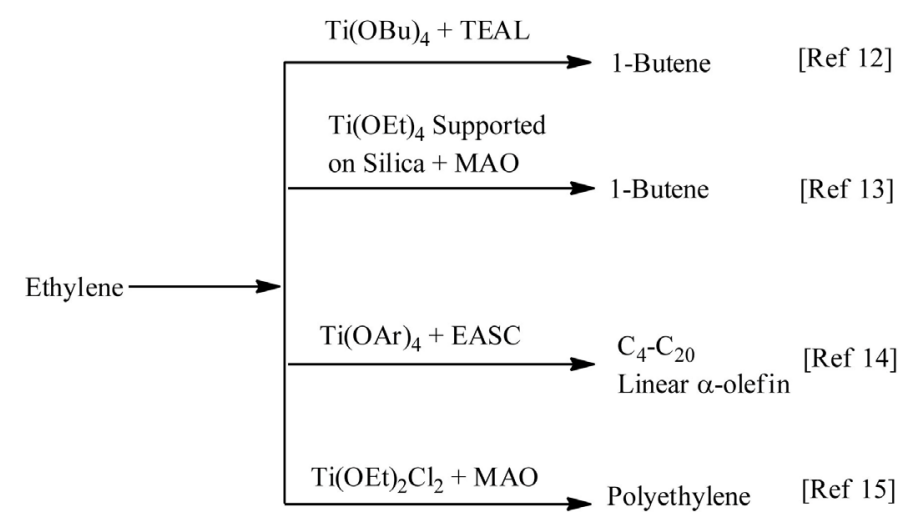

Scheme 1. Products of ethylene oligomerization by titanium alkoxide/aryloxide.

$\left(c-\mathrm{C}_{6} \mathrm{H}_{11}\right)_{7} \mathrm{Si}_{7} \mathrm{O}_{9}(\mathrm{OH})_{3}$ [19]. While a majority of TiPOSS systems have been proven as highly active homogeneous catalyst system for the epoxidation of alkenes $[20,21]$ systematic work on POSS based catalysts for making industrially important polyolefins is, however, lacking $[22,23]$. In order to explore this further we report herein the synthesis of a series of titanium alkoxide complexes tethered to a trisilanol POSS derivative such as (iso-Octyl $)_{7} \mathrm{Si}_{7} \mathrm{O}_{9}(\mathrm{OH})_{3}$. The supported titanium complexes were evaluated in polymerization of ethylene in combination with different alkylaluminum co-catalysts. The influence of reaction conditions on polymer properties has been described.

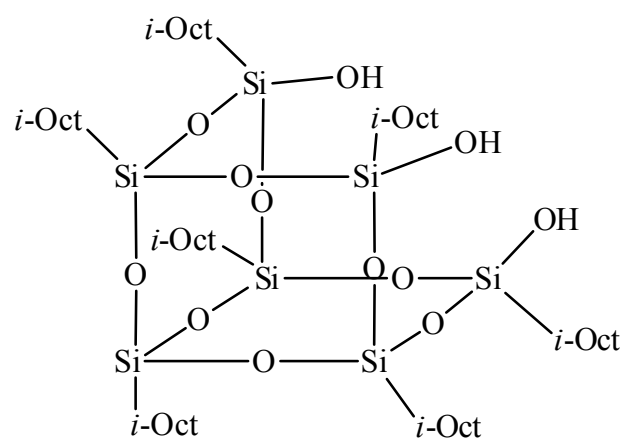

iso-Octyl POSS trisilanol

\section{Experimental}

\subsection{Materials}

All reactions were carried out in an atmosphere of dry nitrogen in a dry box M-Braun (Unilab) or with the use of standard high vacuum Schlenk techniques. Toluene and $n$-pentane were dried over sodium-benzophenone ketyl and freshly distilled under nitrogen atmosphere prior to use and kept over molecular sieves (4A). Polymer grade ethylene ( $>99.95 \%$ purity) was used directly from a commercial plant, the pressure of which was adjusted with a two stage regulator. Alkylaluminum co-catalysts were purchased from Ethyl Corporation $\left(\mathrm{Et}_{3} \mathrm{Al}, \mathrm{Et}_{3} \mathrm{Al}_{2} \mathrm{Cl}_{3}\right.$ ) or Witco GmbH (MAO $10 \%$ in Tolu- ene) and used without further purification. Titanium tetraisopropoxide, Titanium tetraethoxide, Titanium tetrapropoxide, Titanium tetrabutoxide and iso-octyl POSS triol $\left[\mathrm{C}_{56} \mathrm{H}_{119} \mathrm{O}_{9} \mathrm{Si}_{7}(\mathrm{OH})_{3}\right]$ were obtained commercially (Aldrich) and were used as received.

\subsection{Methods of Testing}

Microanalysis was carried out on a Perkin Elmer C, H and $\mathrm{N}$ analyzer. The FT-IR spectra were recorded in $\mathrm{Nu}-$ jol on a Nicolet 6700 FT-IR $\left(400-4000 \mathrm{~cm}^{-1}\right)$ spectrometer. For end group analysis the IR spectra were recorded by pressing the polyethylene powders into 0.5 $\mathrm{mm}$ thick pellets and scanning in the region between 800 $1400 \mathrm{~cm}^{-1}$ with $0.5 \mathrm{~cm}^{-1}$ resolution for 16 scans. ${ }^{1} \mathrm{H}$ NMR spectra of catalysts were recorded on a Varian 300 $\mathrm{MHz}$ instrument using $\mathrm{C}_{6} \mathrm{D}_{6}$ as solvent. ${ }^{29} \mathrm{Si}(79.5 \mathrm{MHz})$ NMR spectra were recorded in $\mathrm{C}_{6} \mathrm{D}_{6}$ solutions on a Brüker $400 \mathrm{MHz}$ spectrometer at $25^{\circ} \mathrm{C}$ with a total of 10000 scans for each sample. The ${ }^{13} \mathrm{C}$ NMR and ${ }^{1} \mathrm{H}$ NMR spectra of polymer samples were recorded on an Ultrashield Brüker $400 \mathrm{MHz}$ spectrometer at $110^{\circ} \mathrm{C}$. The solutions were made up in $o$-dichlorobenzene- $\mathrm{d}_{4}$. The number of scans performed for each spectrum was 512 or 2048 and 2048 or 6144 for ${ }^{1} \mathrm{H}$ and ${ }^{13} \mathrm{C}$ NMR respectively. For the ${ }^{1} \mathrm{H}-\mathrm{NMR}$ spectra the chemical shifts were referenced to residual $\mathrm{H}$ solvent shifts at 7.249. For the ${ }^{13} \mathrm{C}$ NMR spectra the chemical shifts were referenced internally to the major backbone methylene carbon resonance which was taken to be $30.00 \mathrm{ppm}$. FAB mass spectral analysis of catalysts was carried out on a JEOL SX 102/DA - 600 mass spectrometer/data system using Argon/Xenon as the FAB gas, spectra recorded at room temperature. $m$-Nitrobenzyl alcohol was used as the matrix. The accelerated voltage was $10 \mathrm{kV}$. Molecular weights of polymer were determined by size exclusion chromatography. The high temperature gel permeation chromatographic (GPC) analysis of the polymers was carried out with Polymer Lab's PL-GPC 220 chromatograph. A set of three PL Gel Mixed B columns were used. 1,2,4 
Trichlorobenzene was used as the mobile phase at $135^{\circ} \mathrm{C}$. $0.0125 \%$ Irganox was added to the mobile phase before filtration. A sample preparation unit, PL-SP260, was used to dissolve and filter the samples at $135^{\circ} \mathrm{C}$. $0.2 \%$ solutions were injected with the help of an auto sampler to record the chromatogram. Viscotek's Trisec conventional software was used to analyze the chromatograms, which were matched with polystyrene calibration curve. The following MHK constants were used to construct a universal calibration curve. For polystyrene, $K=1.2105$ $e^{-4}$ and $a=707$; for PE, $K=4.055 e^{-4}$ and $a=725$. Differential scanning calorimetry (DSC) was performed under continuous nitrogen purge on a Mettler-Toledo DSC 822 instrument from 30 to $200^{\circ} \mathrm{C}$ at a scan rate of $10^{\circ} \mathrm{C} / \mathrm{min}$. Indium was used to perform calibration of equipment. XRD measurements were carried out on a Brüker AXS model D8 advanced diffractometer. Scattering patterns were obtained with $\mathrm{Ni}$ filled $\mathrm{CuK} \alpha$ radiation $(\lambda=1.5406 \AA$, generator voltage $=45 \mathrm{kV}$, current $=$ $40 \mu \mathrm{A})$ in the reflection mode, as detected by a scintillation counter. Samples were pressed films approximately $400 \mu$ thick and were scanned into $2 \theta$ ranges from $15^{\circ}$ to $45^{\circ}$ at a rate of $1 \% \mathrm{~min}$. Measurements were recorded at steps of $0.02^{\circ}$. Scanning electron micrographs (SEM) of powdered polymer samples were taken on a Jeol JFC 1100 instrument ion sputter water. They were observed in a Jeol $5600 \mathrm{CV}$ scanning electron microscope in $\mathrm{Hv}$ mode at an operating voltage of $20 \mathrm{kV}$.

\subsection{Catalyst Preparation}

Catalysts 1-4 were synthesized by a modified literature procedure (Scheme 2) [20]. In a typical experiment a solution of $0.39 \mathrm{mmol}(0.111 \mathrm{~g})$ of $\mathrm{Ti}\left(\mathrm{OPr}^{i}\right)_{4}$ in toluene $(15 \mathrm{ml})$ was slowly added to $0.38 \mathrm{mmol}(0.451 \mathrm{~g})$ of the corresponding (iso-Octyl) $)_{7} \mathrm{Si}_{7} \mathrm{O}_{9}(\mathrm{OH})_{3}$ ligand in toluene $(15 \mathrm{ml})$ under nitrogen atmosphere and the mixture was heated at $100^{\circ} \mathrm{C}$ for $18 \mathrm{~h}$. The solvent was carefully removed, the viscous gel washed with $n$-pentane and finally a yellow viscous complex was isolated, Yield $0.44 \mathrm{~g}, 78 \%$.

Catalyst $1\left(\mathrm{C}_{59} \mathrm{H}_{126} \mathrm{O}_{13} \mathrm{Si}_{7} \mathrm{Ti}\right)$; Anal calcd. C, 55.01\%; $\mathrm{H}, 9.86 \%$; found: $\mathrm{C}, 55.18 \%$; $\mathrm{H}, 9.55 \%$. ${ }^{1} \mathrm{H}$ NMR $\left(\mathrm{C}_{6} \mathrm{D}_{6}\right.$, $\left.25^{\circ} \mathrm{C}\right): 1.02-1.05\left(42 \mathrm{H}, \mathrm{CH}_{2}-\mathrm{CH}-\left(\mathrm{CH}_{3}\right)_{2} \& 6 \mathrm{H}\right.$,
O-CH- $\left.\left(\mathrm{CH}_{3}\right)_{2}\right), 1.10-1.13\left(70 \mathrm{H},\left(\mathrm{CH}_{2}\right)_{5}-\mathrm{CH}\right), 2.10(7 \mathrm{H}$, $\left.\mathrm{CH}_{2}-\mathrm{CH}-\left(\mathrm{CH}_{3}\right)_{2}\right), 4.3(1 \mathrm{H}, \mathrm{O}-\mathrm{CH})$.

Catalyst 2 Yield $=0.28$ gm, $72 \%\left(\mathrm{C}_{58} \mathrm{H}_{124} \mathrm{O}_{13} \mathrm{Si}_{7} \mathrm{Ti}\right)$; Anal calcd. C, 54.66\%; H, 9.82\%; found: C, 54.73\% H, 9.69\%. ${ }^{1} \mathrm{H}$ NMR $\left(\mathrm{C}_{6} \mathrm{D}_{6}, 25^{\circ} \mathrm{C}\right): 1.02-1.06(42 \mathrm{H}$, $\left.\mathrm{CH}_{2}-\mathrm{CH}-\left(\mathrm{CH}_{3}\right)_{2} \& 3 \mathrm{H}, \mathrm{O}-\mathrm{CH}_{2}-\mathrm{CH}_{3}\right), 1.08-1.12(70 \mathrm{H}$, $\left.\left(\mathrm{CH}_{2}\right)_{5}-\mathrm{CH}\right), 2.20\left(7 \mathrm{H}, \mathrm{CH}_{2}-\mathrm{CH}-\left(\mathrm{CH}_{3}\right)_{2}\right), 3.62(2 \mathrm{H}$, $\mathrm{O}-\mathrm{CH}_{2}$ ).

Catalyst 3 Yield $=0.27$ gm, 68\% $\left(\mathrm{C}_{59} \mathrm{H}_{126} \mathrm{O}_{13} \mathrm{Si}_{7} \mathrm{Ti}\right)$; Anal calcd. C, 55.01\%; H, 9.86\%; found: C, 55.65\%; H, 9.62\%. ${ }^{1} \mathrm{H}$ NMR $\left(\mathrm{C}_{6} \mathrm{D}_{6}, 25^{\circ} \mathrm{C}\right): 1.02-1.06(42 \mathrm{H}$, $\left.\mathrm{CH}_{2}-\mathrm{CH}-\left(\mathrm{CH}_{3}\right)_{2} \& 3 \mathrm{H}, \mathrm{O}-\mathrm{CH}_{2}-\mathrm{CH}_{2}-\mathrm{CH}_{3}\right), 1.11-1.14$ $\left(70 \mathrm{H}, \quad\left(\mathrm{CH}_{2}\right)_{5}-\mathrm{CH} \quad \& \quad 2 \mathrm{H}, \quad \mathrm{O}-\mathrm{CH}_{2}-\mathrm{CH}_{2}\right), 2.12(7 \mathrm{H}$, $\left.\mathrm{CH}_{2}-\mathrm{CH}-\left(\mathrm{CH}_{3}\right)_{2}\right), 3.57\left(2 \mathrm{H}, \mathrm{O}-\mathrm{CH}_{2}\right)$.

Catalyst 4 Yield $=0.24 \mathrm{gm}, 74 \%\left(\mathrm{C}_{60} \mathrm{H}_{128} \mathrm{O}_{13} \mathrm{Si}_{7} \mathrm{Ti}\right)$; Anal calcd. C, 55.32\%; H, 9.92\%; found: C, 54.95\% H, 9.70\%. ${ }^{1} \mathrm{H}$ NMR $\left(\mathrm{C}_{6} \mathrm{D}_{6}, 25^{\circ} \mathrm{C}\right): 1.01-1.04\left(42 \mathrm{H}, \mathrm{CH}_{2^{-}}\right.$ $\left.\mathrm{CH}-\left(\mathrm{CH}_{3}\right)_{2} \& 3 \mathrm{H}, \mathrm{O}-\mathrm{CH}_{2}-\mathrm{CH}_{3}\right), 1.10-1.15(70 \mathrm{H}$, $\left.\left(\mathrm{CH}_{2}\right)_{5}-\mathrm{CH} \& 4 \mathrm{H},\left(\mathrm{CH}_{2}\right)_{2}-\mathrm{CH}_{3}\right), 2.14\left(7 \mathrm{H}, \mathrm{CH}_{2}-\mathrm{CH}-\right.$ $\left.\left(\mathrm{CH}_{3}\right)_{2}\right), 3.61\left(2 \mathrm{H}, \mathrm{O}-\mathrm{CH}_{2}\right)$.

\subsection{General Procedure of Ethylene Polymerization}

Catalytic ethylene polymerization was carried out in a $100 \mathrm{ml}$ stirred autoclave (Model 4593 Parr, USA) connected to a process controller (model 4871) and operated through the microprocessor controller (PC/PLC) using a customized Honeywell specview 32 software. Prior to polymerization, the reactor was heated to $150^{\circ} \mathrm{C}$ under nitrogen for $2 \mathrm{~h}$ and cooled to ambient temperature. In a typical experiment, catalyst $1\left(2.2 \mathrm{mg}, 1.7 \times 10^{-6} \mathrm{~mol}\right)$ dissolved in toluene $(20 \mathrm{ml})$ and $\operatorname{EASC}(0.247 \mathrm{~g}, 9.9 \times$ $\left.10^{-4} \mathrm{~mol}\right)$ in toluene $(20 \mathrm{ml})$ were carefully charged into the reactor under a nitrogen blanket. The Al/Ti was kept at $500(\mathrm{~mol} / \mathrm{mol})$ and the reactor temperature was increased to $100^{\circ} \mathrm{C}$ and then pressurized with ethylene to300 psi. The reaction was terminated after $1 \mathrm{~h}$. The reaction mixture was poured in acidic methanol $(5 \% \mathrm{v} / \mathrm{v})$ to precipitate the polymer. The precipitated white polyethylene powder was filtered, washed several times with methanol followed by acetone and finally dried under vacuum to a constant weight.

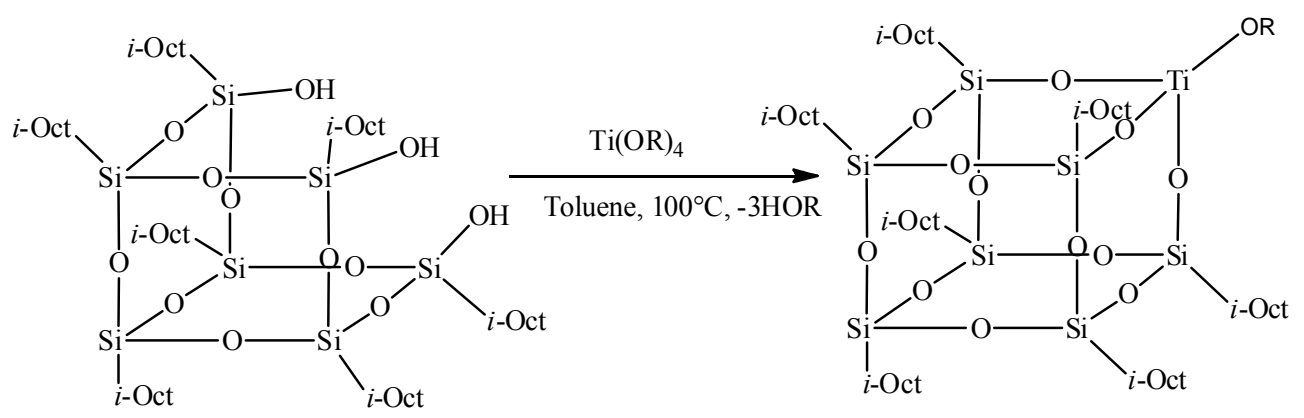

Scheme 2. Synthesis of compounds 1 - 4: $R=\operatorname{Pr}^{i}$ 1, Et 2, Pr 3, Bu 4. 


\section{Results and Discussion}

\subsection{Synthesis of Ti(IV) Complexes with (iso-Octyl) $)_{7} \mathrm{Si}_{7} \mathrm{O}_{9}(\mathrm{OH})_{3}$ and Its Derivatives}

The preparation of titanasilsesquioxane catalysts could be achieved by a stoichiometric reaction between titanium (IV) alkoxide and (iso-Octyl $)_{7} \mathrm{Si}_{7} \mathrm{O}_{9}(\mathrm{OH})_{3}$ ligand (alcohol exchange) in an appropriate solvent and separation of liberated alcohol by azeotropic/vacuum distillation [20,24]. The resulting catalysts 1 - 4 (Scheme 2) were employed for carrying out ethylene polymerization.

\subsection{Catalyst Characterization}

The reaction of $\mathrm{Ti}(\mathrm{OR})_{4}$ and (iso-Octyl $)_{7} \mathrm{Si}_{7} \mathrm{O}_{9}(\mathrm{OH})_{3}$ ligand in toluene afforded yellow coloured viscous catalysts 1 - 4 which are soluble in aromatic solvents but only sparingly in aliphatic hydrocarbons. Catalysts $1-4$ have been characterized by microanalysis, FTIR, UV-Visible, ${ }^{1} \mathrm{H}$ NMR, ${ }^{29} \mathrm{Si}$ NMR and FAB Mass spectra. In the FT-IR spectra of catalyst 1 no peaks were observed in the 3000 $3500 \mathrm{~cm}^{-1}$ region indicating deprotonation of the (isoOctyl $)_{7} \mathrm{Si}_{7} \mathrm{O}_{9}(\mathrm{OH})_{3}$ ligand. However, in the FT-IR of parent (iso-Octyl) $)_{7} \mathrm{Si}_{7} \mathrm{O}_{9}(\mathrm{OH})_{3}$ ligand the band at 890 $\mathrm{cm}^{-1}$ due to the bending mode of $\mathrm{Si}-\mathrm{OH}$ stretching is replaced by a new peak at $928 \mathrm{~cm}^{-1}$ assigned to the presence of Si-O-Ti vibration [25]. In the UV-Visible spectra of 1 , an absorption peak was observed at $215 \mathrm{~nm}$. This absorption is close to the 212 - $228 \mathrm{~nm}$ previously reported for Ti-silsesquioxane complexes and assigned to ligand to metal charge transfer (LMCT) transition involving four co-ordinated titanium bearing oxygen ligand [20].

The ${ }^{29} \mathrm{Si}$ NMR spectrum of catalyst is particularly informative. In the ${ }^{29} \mathrm{Si} \mathrm{NMR}$ spectra of $(i \text {-Octyl })_{7} \mathrm{Si}_{7} \mathrm{O}_{9}(\mathrm{OH})_{3}$ multiplet signals were observed at $\delta=-58,-67$ and -68 ppm (Figure 1(a)). The peak for $\mathrm{Si}-\mathrm{OH}$ is observed at $\delta$ $=-58$ ppm. After complexation with titanium centre (Catalyst 1, Figure 1(b)) the absence of signal at $\delta=-58$ ppm was noted suggesting that the corner capping reaction as shown was successful. In the ${ }^{1} \mathrm{H}$ NMR spectra the set of multiplets at $\delta=1.03-1.06 \mathrm{ppm}$ for $-\mathrm{CH}_{3}$ protons, $1.09-1.13 \mathrm{ppm}$ for $-\mathrm{CH}_{2}$ protons and broad peak at 2.10 ppm for $-\mathrm{CH}$ protons of iso-Octyl group were observed. The signal at $\delta=4.3 \mathrm{ppm}$ was observed for $-\mathrm{CH}$ protons of the iso-propyl group. Feher et al. reported the ${ }^{1} \mathrm{H}$ NMR of incompletely condensed silsesquioxane where in the $\mathrm{Si}-\mathrm{OH}$ signal was observed in the region of $\delta=6$ $6.9 \mathrm{ppm}[26,27]$. The absence of $\mathrm{OH}$ protons in $\delta=6-$ $6.9 \mathrm{ppm}$ region in the catalysts $1-4$ indicates complete deprotonation of the silanol and attachment to the titanium alkoxide. In the FAB mass spectra of catalyst $\mathbf{1}$, theprominent peak for ligand fragment [(iso-Octyl $)_{7} \mathrm{Si}_{7} \mathrm{O}_{9}$ $(\mathrm{OH})_{3}$ ] appeared at 1181 and a low intensity molecular ion peak was observed at 1289 corresponding to the Ti
(POSS) (OPr $\left.{ }^{i}\right)$ species. In an earlier work Edelmann et al. and others showed that the reaction of Ti-tetraethoxide and cyclohexyl-POSS triol lead to dimeric complexes which were characterized by X-ray crystal structure analysis $[20,28,29]$. The concurrent formation of a dimeric compound such as (POSS-OOO)Ti-OPr-Ti (OOO-POSS) along with the mononuclear (POSS-OOO) $\mathrm{Ti}\left(\mathrm{OPr}^{i}\right)$ was observed [16,29]. However, the synthetic method used in this work showed the formation of monomeric species only.

\subsection{Catalytic Ethylene Polymerization}

Unlike the regular polyethylene expected of a Ziegler type catalyst the present (iso-octyl) ${ }_{7} \mathrm{Si}_{7} \mathrm{O}_{9}(\mathrm{OH})_{3}$ supported $\mathrm{Ti}$ (IV) alkoxides produced unusually low molecular weights with the $M_{\mathrm{w}}$ in the $800-1500$ range in all cases. Since the polydispersities are also quite narrow these $\mathrm{PE}$ resemble polyethylene waxes or oligomers within the $\mathrm{C}_{70}$ chain length. Synthetic PE wax is a class of commercial product that has specific end application. The results of ethylene polymerization using catalysts 1 4 are shown in Table $\mathbf{1}$. The polymerization was carried out under different conditions such as temperature, $\mathrm{Al} / \mathrm{Ti}$ ratio, co-catalysts, solvents and ethylene pressure.

Initial examination of catalysts indicate that catalyst 1) containing an iso-propoxide group shows maximum activity while substitution of this pendant group by ethoxide 2), propoxide 3) or butoxide 4) results in considerable reduction in the polymer yields (Table 1, Entries 1 - 4, Figure 2). Apparently steric factors tend to significantly influence the polymerization activity of titanasilsesquioxane catalysts. It was found that the activity of catalysts 1-4 when activated by EASC followed the order $4(\mathrm{OBu})<3(\mathrm{OPr})<$ $2(\mathrm{OEt})<1\left(\mathrm{OPr}^{i}\right)$. This may be explained by the fact that the non-linear iso-propoxide allow better access to the titanium centre than that of linear alkoxy (ethoxy, propoxy and butoxy) groups indicating that accessibility to the $\mathrm{Ti}$ (IV) centre is a parameter influencing the overall activity [20]. The activity is predominantly dependent on the nature of the co-catalyst. Ethylaluminum sesquichloride was found to promote the ethylene polymerization. Other chlorinated alkylaluminum compounds such as ethylaluminum dichloride $\left(\mathrm{EtAlCl}_{2}\right)$ and diethylaluminum chloride $\left(\mathrm{Et}_{2} \mathrm{AlCl}\right)$ are also active but catalyst productivity was slightly lower. In case of the conventional co-catalysts for polyolefin production such as $\mathrm{Et}_{3} \mathrm{Al}$ and $\mathrm{MAO}$ only the latter showed moderate activity while $\mathrm{Et}_{3} \mathrm{Al}$ is practically inactive (Table 2, Entry 5). Moreover, the presence of bulky iso-octyl group attached to silsesquioxane framework probably has a kinetic control on the reaction rate leading to oligomeric $\mathrm{PE}$ product $\left(\mathrm{C}_{70}\right.$ carbon chain). This is in contrast to previous reports on ethylene polymerization on a cyclohexyl silsesquioxane based Ti-catalysts 


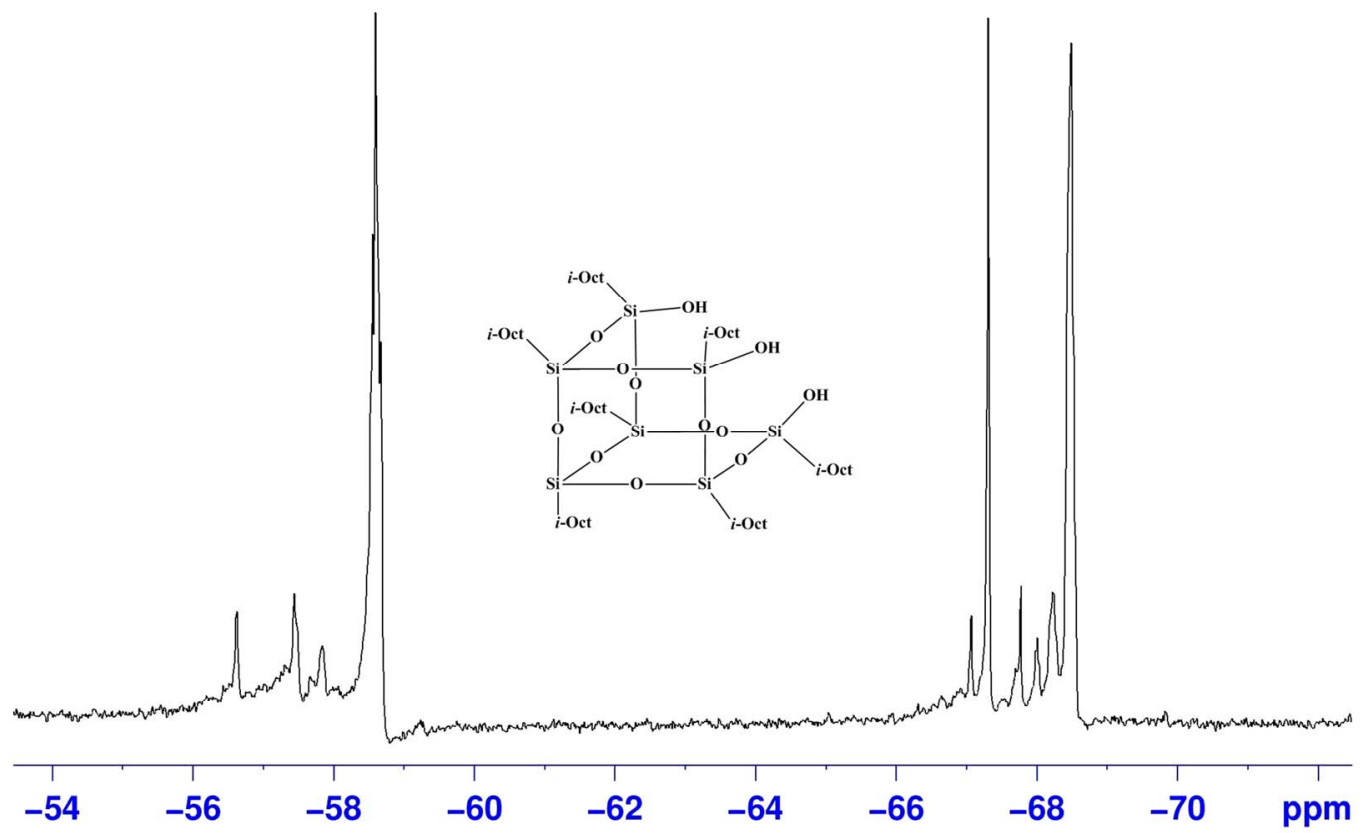

(a)

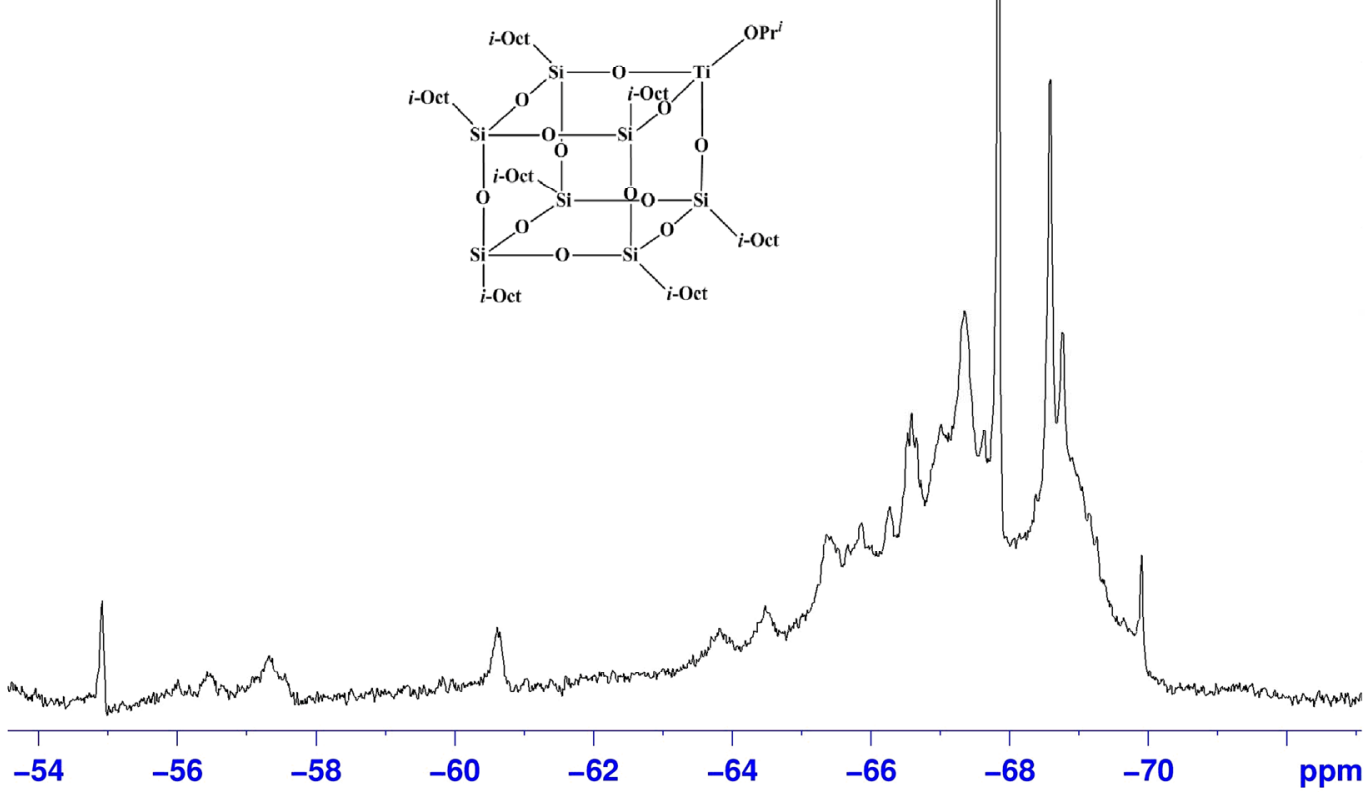

(b)

Figure 1. ${ }^{29} \mathrm{Si} \mathrm{NMR}$ of (iso-octyl) $)_{7} \mathrm{Si}_{7} \mathrm{O}_{9}(\mathrm{OH})_{3}(\mathrm{a})$ and catalyst 1(b). 


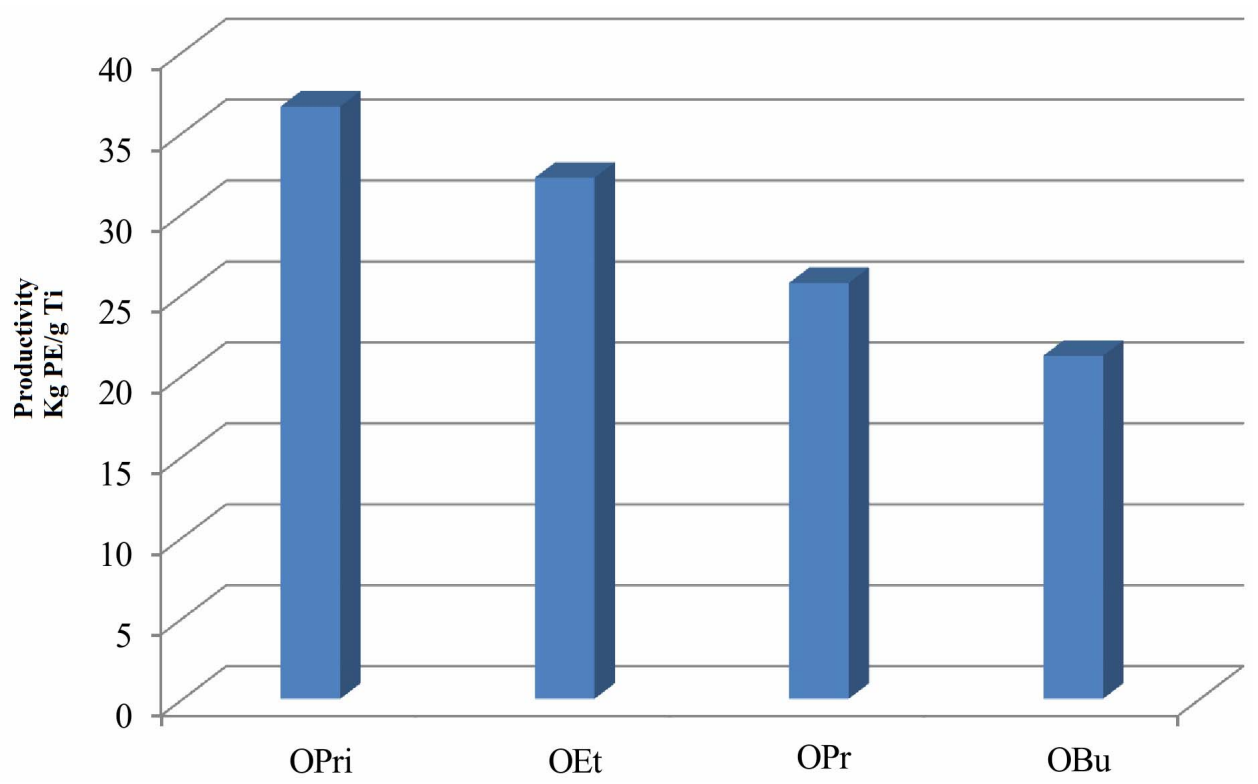

Figure 2. Influence of alkoxy group on ethylene polymerization.

Table 1. Ethylene polymerization with Titanasilsesquioxane-EASC system*.

\begin{tabular}{|c|c|c|c|c|c|c|c|}
\hline \multirow{2}{*}{ Entry } & \multirow{2}{*}{ Catalyst } & \multirow{2}{*}{ Productivity Kg PE/g Ti } & \multirow{2}{*}{$M_{\mathrm{w}}$} & \multirow{2}{*}{ PDI } & \multirow{2}{*}{$T_{\mathrm{m}}\left({ }^{\circ} \mathrm{C}\right)$} & \multicolumn{2}{|c|}{$\%$ Crystallanity $\left(\mathrm{X}_{\mathrm{c}} \%\right)$} \\
\hline & & & & & & XRD & DSC \\
\hline 1 & 1 & 36.6 & 1051 & 1.5 & 122 & 70.7 & 72.3 \\
\hline 2 & 2 & 32.2 & 729 & 1.7 & 117 & 71.2 & 69.6 \\
\hline 3 & 3 & 25.7 & 1146 & 1.6 & 121 & 72.6 & 73.1 \\
\hline 4 & 4 & 21.2 & 927 & 1.7 & 119 & 70.8 & 69.4 \\
\hline $5^{* *}$ & $\mathrm{Ti}(\mathrm{OEt})_{2} \mathrm{Cl}_{2}$ & & $1.3 \times 10^{6}$ & 1.8 & & & \\
\hline
\end{tabular}

${ }^{*}$ All reactions were carried out in a $100 \mathrm{~mL} \mathrm{SS}$ reactor at $100^{\circ} \mathrm{C}$ and $300 \mathrm{psi}$ ethylene pressure for $1 \mathrm{~h}, \mathrm{Al} / \mathrm{Ti}=500(\mathrm{~mol} / \mathrm{mol})$,

${ }^{* *}[15]$.

Table 2. Effect of co-catalysts on ethylene polymerization at $100^{\circ} \mathrm{C}$.

\begin{tabular}{cccc}
\hline Entry & Co-catalyst ${ }^{*}$ & Productivity Kg PE/g Ti & $T_{\mathrm{m}}\left({ }^{\circ} \mathrm{C}\right)$ \\
\hline 1 & EASC & 36.6 & 122 \\
2 & MAO & 9.1 & 133 \\
3 & EADC & 6.1 & 122 \\
4 & DEAC & 2.2 & 124 \\
5 & TEAL & 0.9 & \\
6 & TIBAO & & \\
\hline
\end{tabular}

${ }^{*} \mathrm{EADC}=\mathrm{EtAlCl}_{2}, \mathrm{DEAC}=\mathrm{Et}_{2} \mathrm{AlCl}, \mathrm{TIBAO}=$ Triisobutyldialumoxane, $\mathrm{EASC}=\mathrm{Et}_{3} \mathrm{Al}_{2} \mathrm{Cl}_{3}, \mathrm{TEAL}=\mathrm{Et}_{3} \mathrm{Al}, \mathrm{MAO}=$ Methylalumoxane; Catalyst $\mathbf{1},{ }^{\mathrm{P}} \mathrm{C}_{2} \mathrm{H}_{4}=300$ $\mathrm{psi}, \mathrm{Al} / \mathrm{Ti}=500(\mathrm{~mol} / \mathrm{mol})$.

which generally produced high molecular weight $\mathrm{PE}$ in presence of co-catalyst like $\mathrm{B}\left(\mathrm{C}_{6} \mathrm{~F}_{5}\right)_{3}$ or $\mathrm{MAO}$ [23]. Interestingly, the polyethylene obtained with these titanasilsesquioxane catalysts display narrow molecular weight distribution $\left(M_{\mathrm{w}} / M_{\mathrm{n}}=1.5-1.7\right)$ and low molecular weights corresponding to the $\mathrm{C}_{30}-\mathrm{C}_{70}$ carbon nos.

Detailed studies on the effect of temperature were then carried out employing catalyst $\mathbf{1}$ and EASC as the co-catalyst. From the results summarized in Table $\mathbf{3}$ it is evident that increasing the reaction temperature from 
Table 3. Effect of temperature on polymerization*.

\begin{tabular}{cccc}
\hline Entry & Temp $\left({ }^{\circ} \mathrm{C}\right)$ & $\begin{array}{c}\text { Productivity } \\
\text { Kg PE/g Ti }\end{array}$ & $T_{\mathrm{m}}\left({ }^{\circ} \mathrm{C}\right)$ \\
\hline 1 & 100 & 36.6 & 122 \\
2 & 50 & 19.0 & 123 \\
3 & 27 & 3.9 & 121 \\
\hline
\end{tabular}

${ }^{*}$ Catalyst 1-EASC, ${ }^{\mathrm{P}} \mathrm{C}_{2} \mathrm{H}_{4}=300 \mathrm{psi}, 1 \mathrm{~h}, \mathrm{Al} / \mathrm{Ti}=500(\mathrm{~mol} / \mathrm{mol})$.

ambient to $100^{\circ} \mathrm{C}$ has marked effect on the catalyst activity (Table 3, Entries 1 and 3). Similarly the effect of ethylene pressure on polymerization was investigated and these results are compiled in Table 4. Applying higher pressure under similar conditions lead to an enhancement in productivity of up to $48 \%$ for an increase in ethylene pressure of $7 \mathrm{Kg} / \mathrm{cm}^{2}$ (Table 4, Entries 1 and 2). Generally, a combination of higher $\mathrm{Al} / \mathrm{Ti}$ ratio and a higher temperature lead to improvement in the productivity of the catalyst $36.6 \mathrm{Kg} \mathrm{PE} / \mathrm{g}$ Ti (Table $\mathbf{1}$, Entry 1).

A brief examination of effects of different solvents (Table 5) indicated that chlorinated aromatic solvent such as chlorobenzene gave higher productivity $(45.2 \mathrm{Kg}$ $\mathrm{PE} / \mathrm{g} \mathrm{Ti}$ ) than that observed for toluene (36.6 Kg PE/g Ti). However, other hydrocarbon solvent such as cyclohexane showed poor activity which is probably due to the low solubility of catalysts in this solvent.

To investigate further the properties of these polyethylene reported in Table 1, they were characterized by GPC. The GPC of this material also displays similar distribution in the low molecular weight region (Figure 3). The PE obtained with catalysts 1 - 4 display exceptionally low molecular weights $\left(M_{\mathrm{w}}=729-1146\right)$ and narrow PDI $\left(M_{\mathrm{w}} / M_{\mathrm{n}}=1.5-1.7\right)$. As a benchmark for comparison of polymer properties with that obtained in this work a known sample of micronized polyethylene wax, MPP 635 powder, was used. The reference polyethylene sample is a micronized, high $T_{\mathrm{m}}$, crystalline form of polyethylene which was supplied by M/s Micro Powders, Inc., USA. The product had a $T_{\mathrm{m}}$ value of $125^{\circ} \mathrm{C}$, a molecular weight of $2600, \mathrm{~d}\left(25^{\circ} \mathrm{C}\right)$ of 0.96 , and a maximum particle size of $31 \mu \mathrm{m}$. The values compare well with the $M_{\mathrm{w}}$ (2600) and polydispersity $(\mathrm{PDI}=1.2)$ exhibited by the commercial polyethylene wax powder. In no case was high molecular weight PE $\left(\approx M_{\mathrm{w}} \geq 10^{5}\right)$ obtained although these catalysts resemble typical Ziegler systems. The DSC (Figure 4) also reveals lower $T_{\mathrm{m}}\left(\sim 120^{\circ} \mathrm{C}-122^{\circ} \mathrm{C}\right)$ values than that observed for conventional HDPE or LDPE $\left(128^{\circ} \mathrm{C}-135^{\circ} \mathrm{C}\right)$. The intensity of the equatorial peaks in the X-ray diffractogram (Figure 5) for the 110 $\left(2 \theta=21.4^{\circ}\right)$ and $200\left(2 \theta=23.9^{\circ}\right)$ reflection planes for the experimental sample closely match the intensity of the
Table 4. Effect of pressure on ethylene polymerization*

\begin{tabular}{cccc}
\hline Entry & Pressure (psi) & $\begin{array}{c}\text { Productivity } \\
\text { Kg PE/g Ti }\end{array}$ & $T_{\mathrm{m}}\left({ }^{\circ} \mathrm{C}\right)$ \\
\hline 1 & 400 & 54.9 & 123 \\
2 & 300 & 36.6 & 122 \\
3 & 200 & 14.6 & 121 \\
\hline
\end{tabular}

${ }^{*}$ Catalyst 1-EASC, $100^{\circ} \mathrm{C}, 1 \mathrm{~h}, \mathrm{Al} / \mathrm{Ti}=500(\mathrm{~mol} / \mathrm{mol})$.

Table 5. Influence of solvent on polymerization*"

\begin{tabular}{cccc}
\hline Entry & Solvent & $\begin{array}{c}\text { Productivity } \\
\text { Kg PE/g Ti }\end{array}$ & $T_{\mathrm{m}}\left({ }^{\circ} \mathrm{C}\right)$ \\
\hline 1 & Toluene & 36.6 & 122 \\
2 & Chlorobenzene & 45.2 & 125 \\
3 & Cyclohexane & 6.1 & \\
\hline
\end{tabular}

${ }^{*}$ Catalyst 1-EASC, ${ }^{\mathrm{P}} \mathrm{C}_{2} \mathrm{H}_{4}=300 \mathrm{psi}, 1 \mathrm{~h}, \mathrm{Al} / \mathrm{Ti}=500(\mathrm{~mol} / \mathrm{mol})$

commercial sample and the pattern is indicative of orthorhombic crystallinity in these samples.

The crystalline nature of these polymers was estimated by integration of the X-ray diffraction peaks observed. A high degree of crystallinity was indicated in all cases, which was in the range of $69 \%-76 \%$. The polyethylene powders isolated after polymerization were generally observed to be fine particles $(<500 \mu \mathrm{m})$ having uniform morphology as seen by scanning electron microscopy. A typical scanning electron micrograph (SEM) is reproduced in Figure 6. The morphology compares well with that of the commercial sample though the latter products are micronized $(15-30 \mu)$ by a separate process for end use. It is therefore possible to tailor the $M_{\mathrm{w}}$ and polydispersities of the polyethylene obtained by the titanasilsesquioxane-EASC catalyst system as per desired commercial application.

\subsection{Polymer Microstructure}

End group analysis of PE was made using ${ }^{1} \mathrm{H} N M R,{ }^{13} \mathrm{C}$ NMR and FT-IR spectroscopic methods. In the ${ }^{1} \mathrm{H}$ NMR spectra of $\mathrm{PE}$ a strong signal at $1.33 \mathrm{ppm}$ was observed for the main chain methylene protons $\left(-\mathrm{CH}_{2}-\mathrm{CH}_{2}-\right)_{\mathrm{n}}$. A signal of lower intensity at $0.90 \mathrm{ppm}$ (Figure 7) was ascribed to the methyl end group protons $\left(-\mathrm{CH}_{3}\right)$. However, the intensity of the methyl proton is small due to the low concentration with respect to the main chain methylene protons. Likewise, in the olefinic region much weaker signal assigned to the vinyl chain end $\left(\mathrm{CH}_{2}=\mathrm{CH}-\right)$ at 4.9 $5.0 \mathrm{ppm}$ and vinylidene group $\left(\mathrm{CH}_{2}=\mathrm{CH}-\right)$ at $5.78-$ $5.82 \mathrm{ppm}$ were observed respectively. An additional very weak signal was observed at $3.56-3.59 \mathrm{ppm}$ which is 


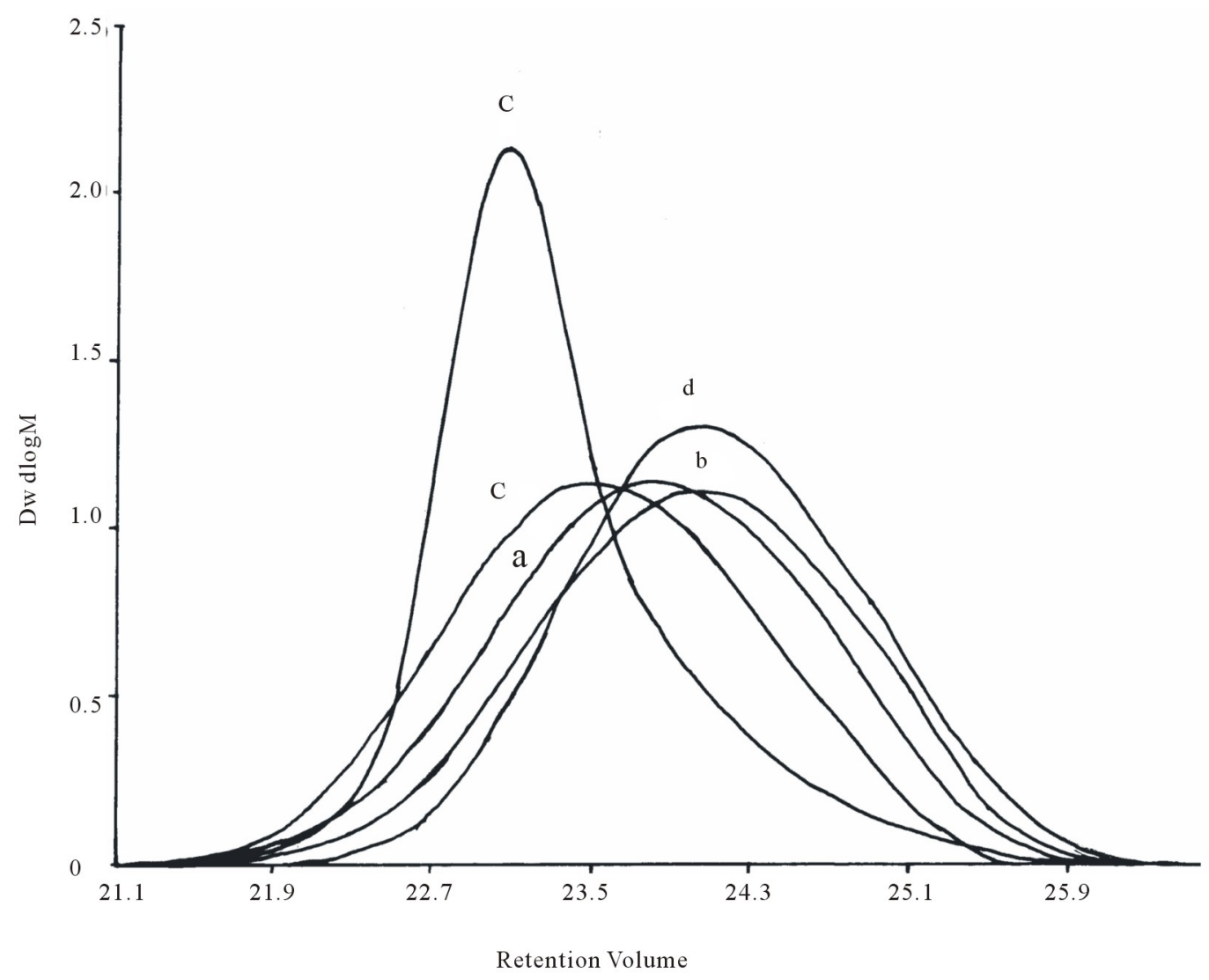

Figure 3. GPC of polyethylene Table 1: (a) entry 1, (b) entry 2, (c) entry 3, (d) entry 4 and (e) MPP - 635.

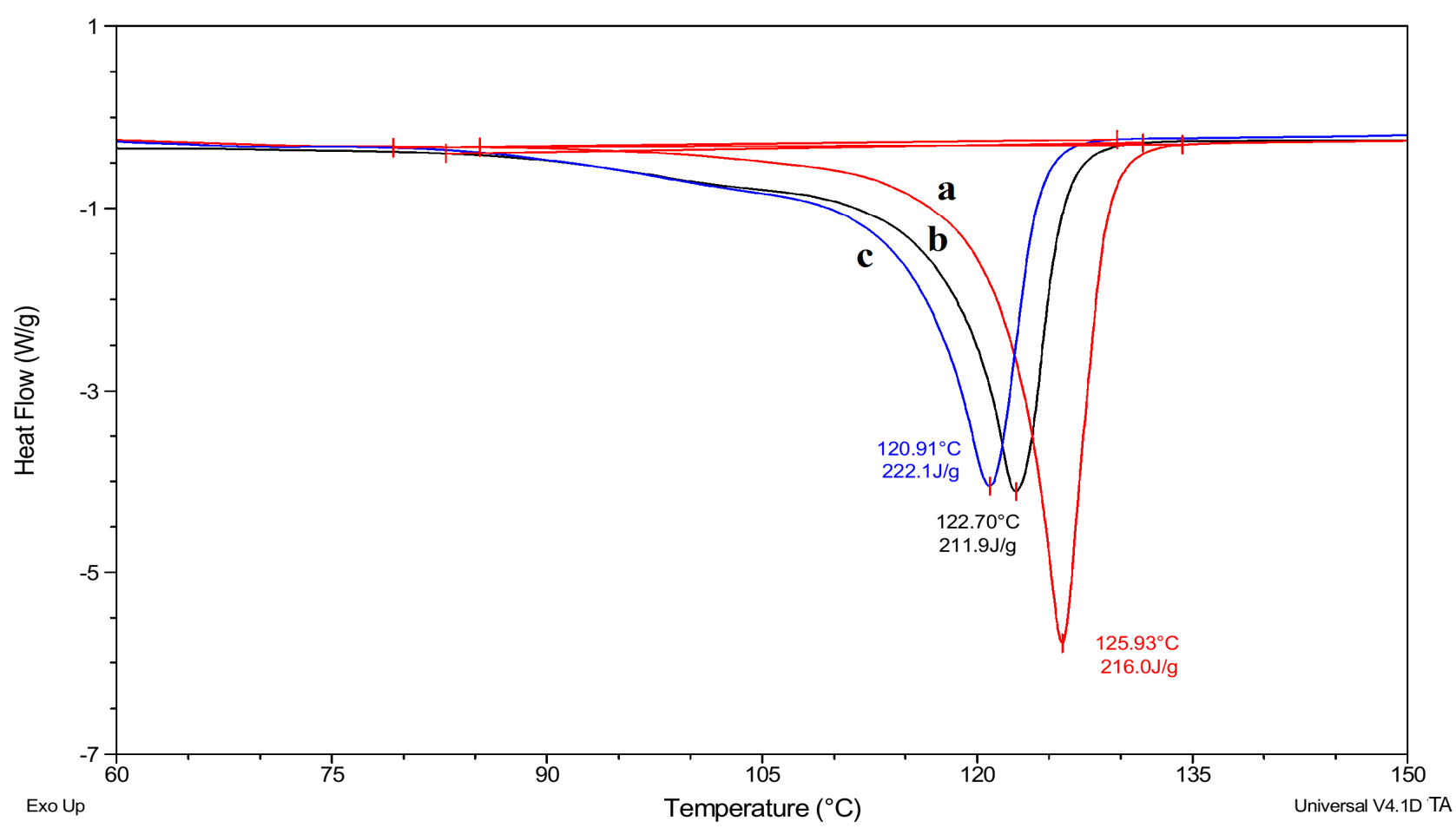

Figure 4. DSC of PEs MPP - 635: (a) Table 1, entry 1 (b) and entry 3 (c). 


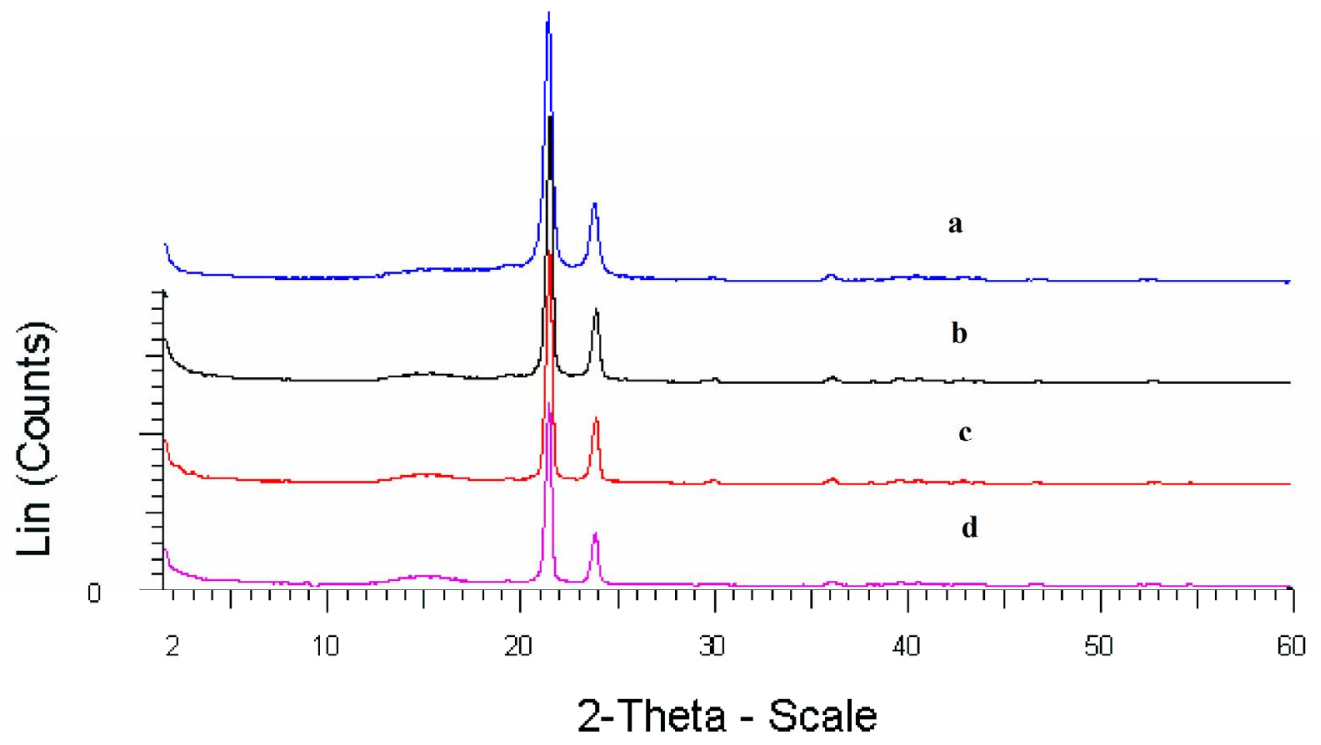

Figure 5. XRD of PEs: (a) MPP - 635, Table 1, entry 1 (b), entry 2 (c) and entry 3 (d).
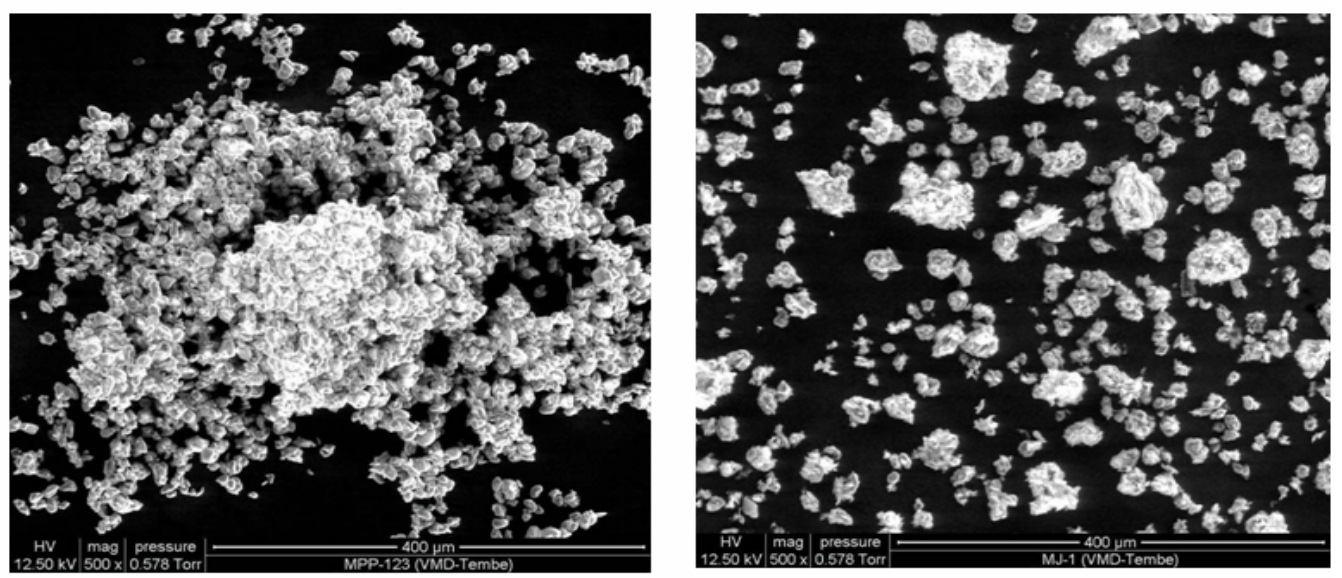

Figure 6. SEM of PEs MPP - 635 (Left) and Table 1, entry 1 (Right).

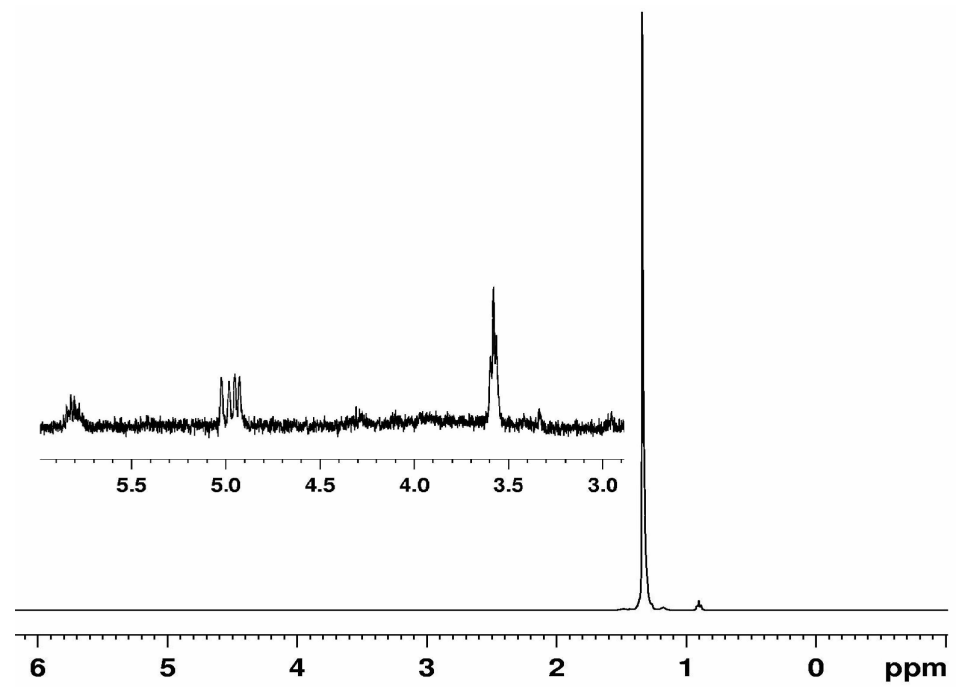

Figure 7. ${ }^{1} \mathrm{H}$ NMR of PE Table 1 and entry 1. 
assigned to the presence of hydroxymethyl end group $\left(-\mathrm{CH}_{2} \mathrm{OH}\right)$ in polyethylene, probably arising due to the transfer of active titanium centre to aluminum of EASC followed by exposure to oxygen to the resulting $\mathrm{C}-\mathrm{Al}$ bonds during post reaction work up which converts to the hydroxy group (Equation (1)) [30,31]. These results suggest that obtained $\mathrm{PE}$ is a linear polymer.

$$
\begin{gathered}
\mathrm{Et}_{2} \mathrm{ClAl}-\mathrm{CH}_{2}-\mathrm{CH}_{2}-\mathrm{P} \\
\mathrm{Et}_{2} \mathrm{Cl}_{2} \mathrm{Al}-\mathrm{CH}_{2}-\mathrm{CH}_{2}-\mathrm{P}
\end{gathered} \stackrel{\mathrm{O}_{2} / \mathrm{H}_{+}}{\longrightarrow} \mathrm{HO}-\mathrm{CH}_{2}-\mathrm{CH}_{2}-\mathrm{P}
$$

The ${ }^{13} \mathrm{C}$ NMR spectra (Figure 8) showed a strong signal at $30.0 \mathrm{ppm}$ (B4) for the main chain methylene carbons $\left(-\mathrm{CH}_{2}-\mathrm{CH}_{2}\right)_{\mathrm{n}}$ of $\mathrm{PE}$ and the lower intensity signals at $14.08 \mathrm{ppm}(\mathrm{B} 1)-\mathrm{CH}_{3}, 22.87 \mathrm{ppm}$ (B2) $\alpha-\mathrm{CH}_{2}, 32.17$ ppm (B3) $\beta-\mathrm{CH}_{2}$ which are ascribed to the chain ends
(Equation (2)) [32,33]. These results clearly support that synthesized PE is linear in nature.

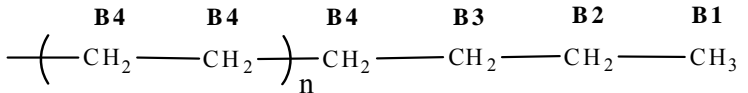

As a benchmark for comparison, the ${ }^{1} \mathrm{H}$ NMR and ${ }^{13} \mathrm{C}$ NMR spectra of commercial sample MPP - 635 were studied. In general, both ${ }^{1} \mathrm{H}$ and ${ }^{13} \mathrm{C}$ NMR spectrum of MPP - 635 was similar to the spectra discussed above (Figures 9 and 10).

In the FT - IR spectrum of polyethylene vinyl peaks at $908 \mathrm{~cm}^{-1} \& 991 \mathrm{~cm}^{-1}$ and vinylidene peak at $888 \mathrm{~cm}^{-1}$ as well as an absorption band at $1050 \mathrm{~cm}^{-1}$ attributed to the presence of hydroxy-methyl end group in polyethylene were clearly observed. Their presence was confirmed by ${ }^{1} \mathrm{H}$ NMR spectroscopy as discussed above [31,34]. In

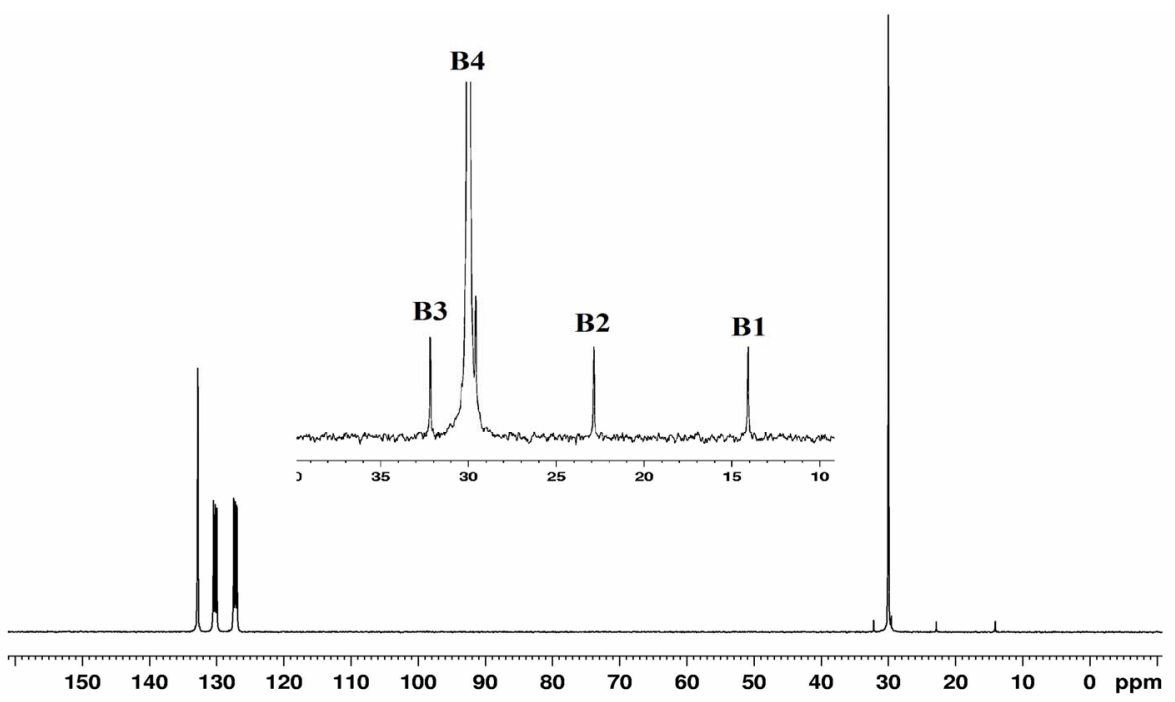

Figure 8. ${ }^{13} \mathrm{C}$ NMR of PE Table 1 and entry 1.

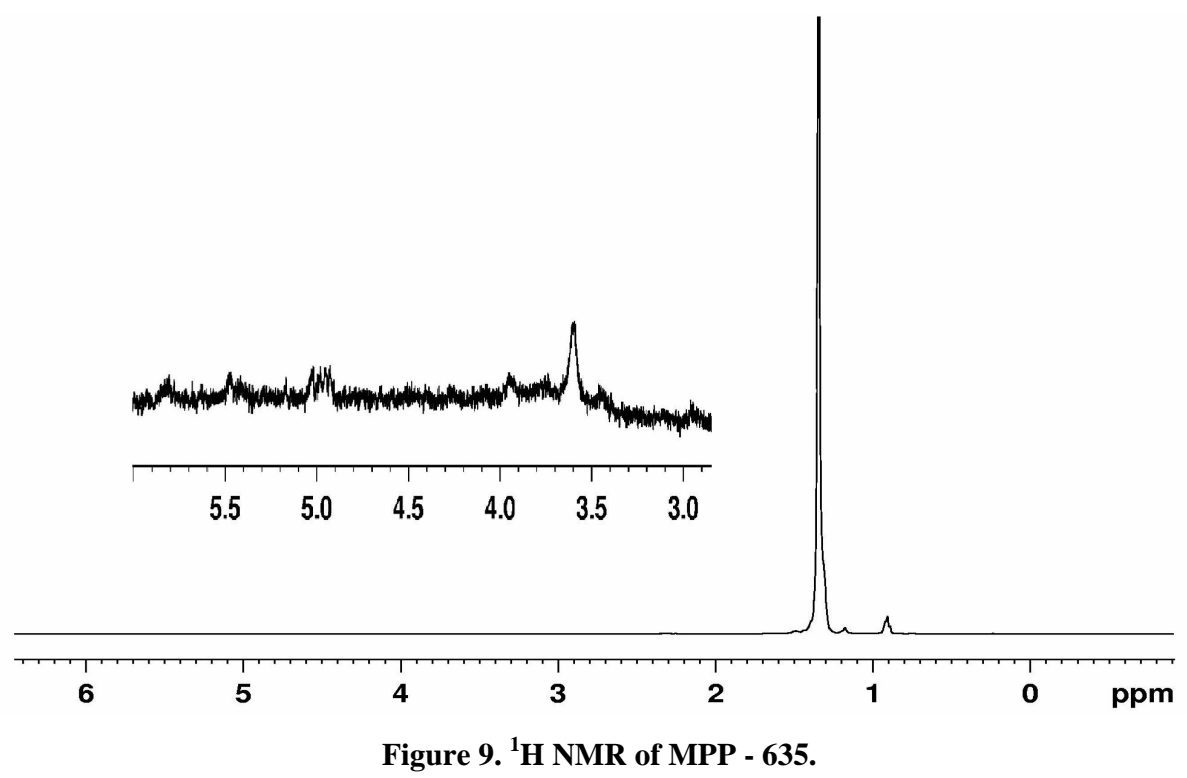




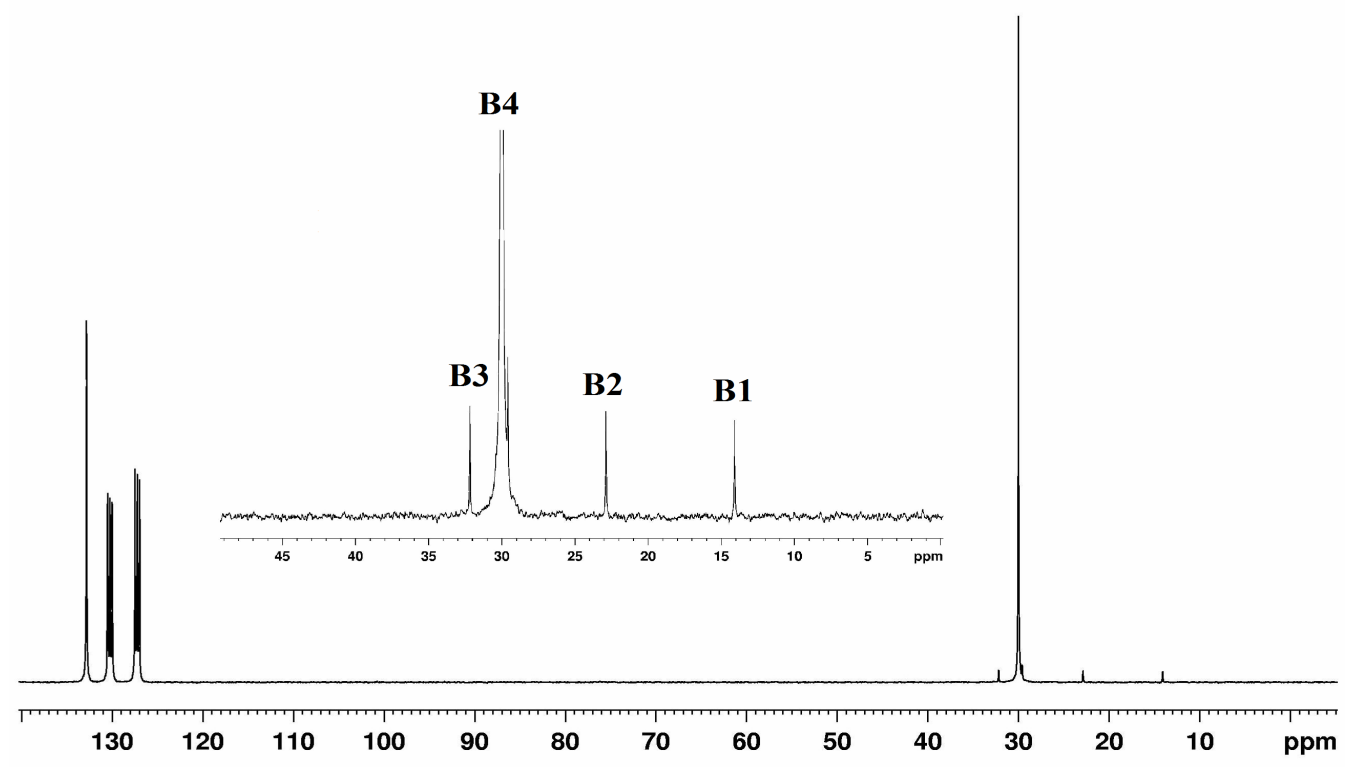

Figure 10. ${ }^{13} \mathrm{C}$ NMR of MPP - 635.

addition, the characteristic absorbance band at $1376 \mathrm{~cm}^{-1}$ was assigned to the $-\mathrm{CH}_{3}$ group of polyethylene. As a benchmark for the comparison of the polymer properties with those obtained in this study, commercial PE wax sample MPP - 635 was used. The ratio of unsaturated end group (vinyl) to saturated end group (methyl) of polyethylene was calculated as 0.96:1. The almost equal proportion $(1: 1)$ of these end groups supports the formation of linear polyethylene [35].

The obtained results showed that the synthesized polyethylenes possess linear structure and the presence of chain end groups indicate that chain transfer to aluminum is predominant in the catalytic reaction; the resultant polymer has low molecular weight with narrow PDI.

\subsection{Reaction Mechanism}

Treatment of mononuclear $\mathrm{Ti}(\mathrm{OR})_{4}$ type alkoxides with alkylaluminum halides has been reported to yield active intermediates responsible for the polymerization of ethylene to low molecular weight products [36-39].

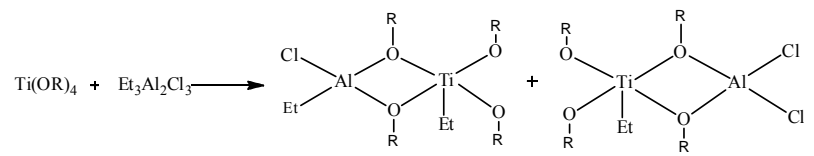

We believe that similar type of active species may be involved in the present titanasilsesquioxne system. Moreover, as EASC is derived from an equimolar mixture of EADC and DEAC [40], we have,

$$
2 \mathrm{Et}_{3} \mathrm{Al}_{2} \mathrm{Cl}_{3} \text { 日时 }\left(\mathrm{EtAlCl}_{2}\right)_{2}+\left(\mathrm{Et}_{2} \mathrm{AlCl}\right)_{2}
$$

Since EASC can dissociate as $\mathrm{Et}_{2} \mathrm{AlCl}$ and $\mathrm{EtAlCl}_{2}$ in solution it is reasonable to expect the formation of two types of catalytic species on interaction with titanasilsesquioxane catalyst.

The reduction of $\mathrm{Ti}$ (IV) in presence of EASC will generate catalytically active components. As shown in Scheme 3 the active catalysts in polymerization need to retain monomeric four or five coordinate geometry to allow for olefin insertion and subsequent propagation/chain termination to aluminum alkyl. In the present titanasilsesquioxane catalytic system higher temperature tends to favour formation of active intermediates responsible for polymerization.

Based on this hypothesis it is possible to predict the pathway shown in Scheme 3 for the formation of polyethylene. Though the structure of active intermediate is as yet unknown the mechanism leading to polyethylene is consistent with those reported previously for solution phase olefin polymerization using titanium alkoxides and aluminum alkyls $[41,42]$ and cyclopentadienyl Ti-POSS complexes with MMAO [43]. Efforts are underway to investigate the detailed kinetics of this reaction.

\section{Conclusion}

Alkoxides of Titanium (IV) supported on polyhedral oligomeric silsesquioxane act as efficient catalysts in the presence of EASC as co-catalyst for the synthesis of specialty low-molecular weight PE with good productivities. The catalyst activity was significantly influenced by the reaction temperature and $\mathrm{Al} / \mathrm{Ti}$ ratios. The physical properties exhibited by these linear polyethylenes such as low molecular weight, high crystallinity and narrow PDI suggest single-site catalytic behavior of these supported titanasilsesquioxane catalysts. The close resemblance of polymer properties to that of commercially important PE 


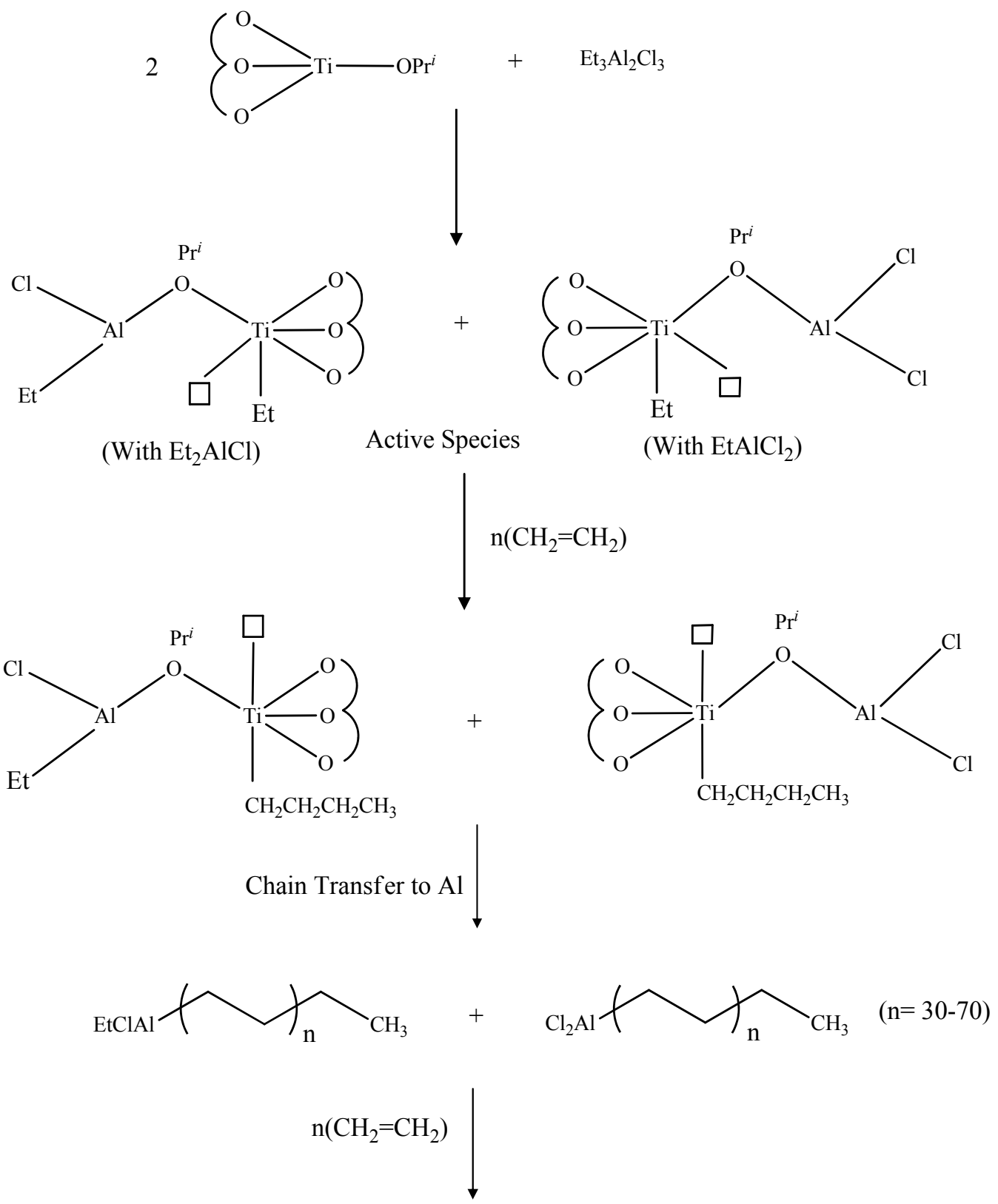

\section{Polyethylene}

Scheme 3. Proposed mechanism of ethylene polymerization by titanasilsesquioxane catalyst system.

waxes holds promise for development of alternative catalysts for this process.

\section{Acknowledgements}

One of the authors (AMM) gratefully acknowledges the management of Reliance Industries Limited for use of its technical facility and the Head, Department of Applied Chemistry, S. V. National Institute of Technology of Surat for supporting this work. The authors also thank the Regional Sophisticated Instrumentation Centre, IIT
Mumbai and Central Drug Research Lab., Lucknow, for NMR and FAB mass spectral analysis.

\section{REFERENCES}

[1] D. S. McGuinness, "Olefin Oligomerization via Metallacycles: Dimerization, Trimerization, Tetramerization, and Beyond," Chemical Reviews, Vol. 111, No. 3, 2011, pp. 2321-2341. doi:10.1021/cr100217q

[2] D. F. Wass, "Chromium-Catalyzed Ethene Trimerization and Tetramerization-Breaking the Rules in Olefin Oli- 
gomerization," Dalton Transactions, No. 8, 2007, pp. 816-819. doi:10.1039/b616291f

[3] G. J. P. Britovsek, V. C. Gibson and D. F. Wass, "The Search for New-Generation Olefin Polymerization Catalysts: Life beyond Metallocenes," Angewandte Chemie, International Edition, Vol. 38, No. 4, 1999, pp. 428-447. doi:10.1002/(SICI)1521-3773(19990215)38:4<428::AIDANIE428>3.0.CO;2-3

[4] J. T. Dixon, M. J. Green, F. M. Hess and D. H. Morgan, "Advances in Selective Ethylene Trimerization-A Critical Overview," Journal of Organometallic Chemistry, Vol. 689, No. 23, 2004, pp. 3641-3668. doi:10.1016/j.jorganchem.2004.06.008

[5] F. J. Karol, K. J. Cann and B. E. Wagner, "Transition metals and Organometallics as Catalysts for Olefin Polymerization," In: W. Kaminsky and H. Sinn, Eds., SpringerVerlag: New York, 1988, 442 p.

[6] G. G. Hlatky, "Heterogeneous Single Site Catalysts for Olefin Polymerization," Chemical Reviews, Vol. 100, No. 4, 2000, pp. 1347-1376. doi:10.1021/cr9902401

[7] E. I. Iiskola, S. Timonen, T. T. Pakkanen, O. Härkki, P. Lehmus and J. V. Seppälä, "Cyclopentadienyl Surface as a Support for Zirconium Polyethylene Catalysts," Macromolecules, Vol. 30, No. 10, 1997, pp. 2853-2859. doi:10.1021/ma960739m

[8] T. Arai, H. T. Ban, T. Uozumi and K. Soga, "Synthesis of Poly(Siloxane)-Supported Zirconocene Catalysts and Application to Olefin Polymerizations," Journal of Polymer Science a Polymer Chemistry, Vol. 36, No. 3, 1998, pp. 421-428.

doi:10.1002/(SICI)1099-0518(199802)36:3<421::AID-P OLA6>3.0.CO;2-U

[9] D. G. H. Ballard, "Pi and Sigma Transition Metal Carbon Compounds as Catalysts for the Polymerization of Vinyl Monomers and Olefins," Advances in Catalysis, Vol. 23, 1973, pp. 263-325. doi:10.1016/S0360-0564(08)60303-X

[10] J. Schwartz and M. D. Ward, "Silica Supported Zirconium Hydrides as Isomerization or Hydrogenation Catalysts for Long Chain Olefins," Journal of Molecular Catalysis, Vol. 8, No. 4, 1980, pp. 465-469. doi:10.1016/0304-5102(80)80085-X

[11] S. A. King and J. Schwartz, "Chemistry of (Silica) Zirconium Dihydride," Inorganic Chemistry, Vol. 30, No. 19, 1991, pp. 3771-3774. doi:10.1021/ic00019a040

[12] S. M. Pillai, G. L. Tembe, M. Ravindranathan and S. Sivaram, "Dimerization of Ethylene to 1-Butene Catalyzed by the Titanium Alkoxide-Trialkylaluminum System," Industrial \& Engineering Chemistry Research, Vol. 27, No. 11, 1988, pp. 1971-1977. doi:10.1021/ie00083a003

[13] P. D. Smith, D. D. Klendworth and M. P. McDaniel, "Ethylene Dimerization over Supported Titanium Alkoxides," Journal of Catalysis, Vol. 105, No. 1, 1987, pp. 187-198. doi:10.1016/0021-9517(87)90018-2

[14] G. L. Tembe and M. Ravindranathan, "Oligomerization of Ethylene to Linear an Olefins by a Titanium Aryl Oxide-Alkylaluminum Catalyst," Industrial \& Engineering Chemistry Research, Vol. 30, No. 10, 1991, pp. 2247-
2252. doi:10.1021/ie00058a002

[15] T. Gueta-Neyroud, B. Tumanskii, M. Kapon and M. S. Eisen, "Synthesis and Characterization of Dichlorotitanium Alkoxide Complex and Its Activity in the Polymerization of $\alpha$-Olefins," Macromolecules, Vol. 40, No. 15, 2007, pp. 5261-5270. doi:10.1021/ma070771o

[16] R. W. J. M. Hanssen, A. Meetsma, R. A. van Santen and H. C. L. Abbenhuis, "Synthesis, Structure Characterization, and Transmetalation Reactions of a Tetranuclear Magnesium Silsesquioxane," Inorganic Chemistry, Vol. 40, No. 16, 2001, pp. 4049-4052. doi:10.1021/ic0004131

[17] R. Duchateau, "Incompletely Condensed Silsesquioxanes: Versatile Tools in Developing Silica-Supported Olefin Polymerization Catalysts", Chemical Reviews, Vol. 102, No. 10, 2002, pp. 3525-3542. doi:10.1021/cr010386b

[18] F. J. Feher, T. A. Budzichowski, K. Rahimian and J. W. Ziller, "Reaction of Incompletely Condensed Silsesquioxanes with Pentamethylantimony: A New synthesis of Metallasilsesquioxanes with Important Implications for the Chemistry of Silica Surfaces," Journal of American Chemical Society, Vol. 114, No. 10, 1992, 3859-3866. doi: $10.1021 / \mathrm{ja} 00036 \mathrm{a} 038$

[19] F. J. Brown and L. H. Vogt, "The Polycondensation of Cyclohexylsilanetriol," Journal of American Chemical Society, Vol. 87, No. 19, 1965, pp. 4313-4317. doi: $10.1021 / \mathrm{ja} 00947 \mathrm{a} 016$

[20] M. Crocker, R. H. M. Herold, A. G. Orpen and M. T. A. Overgaag, "Synthesis and Characterisation of Titanium Silasesquioxane Complexes: Soluble Models for the Active Site in Titanium Silicate Epoxidation Catalysts," Journal of Chemical Society, Dalton Transaction, No. 21, 1999, pp. 3791-3804. doi:10.1039/a905887g

[21] P. P. Pescarmona, J. C. van der Waal, I. E. Maxwell and T. Maschmeyer, "A New, Efficient Route to TitaniumSilsesquioxane Epoxidation Catalysts Developed by Using High-Speed Experimentation Techniques," Angewandte Chemie International Edition in English, Vol. 40, No. 4, 2001, pp. 40-43.

[22] R. Duchateau, R. A. van Santen and G. P. A. Yap, "Silica-Grafted Borato Cocatalysts for Olefin Polymerization Modeled by Silsesquioxane Borato Complexes," Organometallics, Vol. 19, No. 5, 2000, pp. 809-816.

[23] R. Duchateau, U. Cremer, R. J. Harmsen, S. I. Mohamud, H. C. L. Abbenhuis, R. A. van Santen, A. Meetsma, S. K. H. Thiele, M. F. H. van Tol and M. Kranenbürg, "Half-Sandwich Group 4 Metal Siloxy and Silsesquioxane Complexes: Soluble Model Systems for Silica Grafted Olefin Polymerization Catalysts," Organometallics, Vol. 18, No. 26, 1999, pp. 5447-5459.

doi:10.1021/om9904495

[24] P. P. Pescarmona, J. J. T. Rops, J. C. van der Waal, J. C. Jansen and T. Maschmeyer, "High Speed Experimentational Techniques Applied to the Study of the Synthesis of Zeolites and Silsesquioxane," Journal of Molecular Catalysis Part A Chemical, Vol. 182-183, 2002, pp. 319325. doi:10.1016/S1381-1169(01)00494-0

[25] F. Carniato, E. Boccaleri and L. Marchese, “A Versatile Route to Bifunctionalized Silsesquioxane (POSS): Synthesis and Characterisation of Ti-containing Aminopropy- 
lisobutyl-POSS," Dalton Transactions, No. 1, 2008, pp. 36-39. doi:10.1039/b715664m

[26] F. J. Feher, D. A. Newman and J. F. Walzer, "Silsesquioxanes as Models for Silica Surfaces," Journal of American Chemical Society, Vol. 111, No. 5, 1989, pp. 17411748. doi:10.1021/ja00187a028

[27] F. J. Feher, T. A. Budzichowski, R. L. Blanski, K. J. Weller and J. W. Ziller, "Facile Syntheses of New Incompletely Condensed Polyhedral Oligosilsesquioxanes: $\left[\left(c-\left(\mathrm{C}_{5} \mathrm{H}_{9}\right)_{7} \mathrm{Si}_{7} \mathrm{O}_{9}(\mathrm{OH})_{3}\right], \quad\left[\left(c-\left(\mathrm{C}_{7} \mathrm{H}_{13}\right)_{7} \mathrm{Si}_{7} \mathrm{O}_{9}(\mathrm{OH})_{3}\right], \quad\right.\right.$ and $\left[\left(c-\left(\mathrm{C}_{7} \mathrm{H}_{13}\right)_{7} \mathrm{Si}_{6} \mathrm{O}_{7}(\mathrm{OH})_{4}\right]\right.$," Organometallics, Vol. 10, No. 7, 1991, pp. 2526-2528. doi:10.1021/om00053a070

[28] M. Crocker, R. H. M. Herold and A. G. Orpen, "Synthesis and Structural Characterisation of Tripodal Titanium Silsesquioxane Complexes: A New Class of Highly Active Catalysts for Liquid Phase Alkene Epoxidation," Chemical Communications, No. 24, 1997, pp. 2411-2412. doi:10.1039/a704969b

[29] F. T. Edelmann, S. Gießmann and A. Fischer, "Silsesquioxane Chemistry 4 Silsesquioxane Complexes of Titanium (III) and Titanium (IV)," Journal of Organometallic Chemistry, Vol. 620, No. 1-2, 2001, pp. 80-89. doi:10.1016/S0022-328X(00)00867-6

[30] E. Keren and G. Sundararajan, "Polymerization of 1Olefins by Zirconium/Titanium Precatalysts with $\mathrm{O}, \mathrm{N}$, O-Ligating Atoms-Can Aggregation of Catalyst be Inferred from the Reaction Profile?" Journal of Polymer Science Part A: Polymer Chemistry, Vol. 45, No. 16, 2007, pp. 3599-3610. doi:10.1002/pola.22109

[31] M. Białek, "Effect of Catalyst Composition on ChainEnd-Group of Polyethylene Produced by Salen-Type Complexes of Titanium, Zirconium, and Vanadium," Journal of Polymer Science Part A: Polymer Chemistry, Vol. 48, No. 14, 2010, pp. 3209-3214. doi:10.1002/pola.24096

[32] A. Kaji, Y. Akimoto and A. Murano, "NMR Study of Microstructure of Ultra High-Molecular Weight Polyethylene," Journal of Polymer Science Part A: Polymer Chemistry, Vol. 29, No. 13, 1991, pp. 1987-1991. doi:10.1002/pola.1991.080291320

[33] Y. Li, L. Wang, H. Gao, F. Zhu and Q. Wu, "Novel Nickel (II) Complexes Chelating $\beta$-Diketiminate Ligands: Synthesis and Simultaneous Polymerization and Oligomerization," Applied Organometallic Chemistry, Vol. 20, No. 7, 2006, pp. 436-442. doi:10.1002/aoc.1097

[34] E. Aitola, K. Hakala, H. B. Fagerholm, M. Leskela and T. Repo, "High Molar Mass Ethene/1-Olefin Copolymers Synthesized with Acenaphthyl Substituted Metallocene Catalysts," Journal of Polymer Science Part A: Polymer
Chemistry, Vol. 46, No. 1, 2008, pp. 373-382. doi: $10.1002 /$ pola. 22387

[35] G. J. P. Britovsek, M. Bruce, V. C. Gibson, B. S. Kimberley, P. J. Meddox, S. Mastroianni, S. J. McTavish, C. Redshaw, G. A. Solan, S. Stromberg, A. J. P. White and D. J. Williams, "Iron and Cobalt Ethylene Polymerization Catalysts Bearing 2, 6-Bis(Imino) Pyridyl Ligands: Synthesis, Structures, and Polymerization Studies," Journal of American Chemical Society, Vol. 121, No. 38, 1999, pp. 8728-8740. doi:10.1021/ja990449w

[36] H. Hirai, K. Hiraki, I. Noguchi and S. Makishima, "Electron Spin Resonance Study on Homogeneous Catalysts Derived from $n$-Butyl Titanate and Triethylaluminum," Journal of Polymer Science Part A, Vol. 8, No. 1, 1970, pp. 147-156. doi:10.1002/pol.1970.150080113

[37] P. H. Moyer, "Studies of the Reduction of Titanates and Alkoxytitanium (IV) Chlorides by Alkylaluminum Chlorides," Journal of Polymer Science A, Vol. 3, No. 1, 1965, pp. 199-207. doi:10.1002/pol.1965.100030122

[38] E. Angelescu, C. Nicolau and Z. Simon, "Electron Spin Resonance Investigations of Some Soluble Organometallic," Journal of American Chemical Society, Vol. 88, No. 17, 1966, pp. 3910-3912. doi:10.1021/ja00969a004

[39] R. A. Rothenbury, "Anomalous Effects of Catalyst Mole Ratio on Molecular Weight of Ziegler Polyethylene," Journal of Polymer Science Part A, Vol. 3, No. 8, 1965, pp. 3038-3039.

[40] T. Mole and E. A. Jeffery. "Organoaluminium Compounds," Elsevier, New York, 1972.

[41] R. D. J. Froese, D. G. Musaev, T. Matsubara and K. Morokuma, "Theoretical Studies of Ethylene Polymerization Reactions Catalyzed by Zirconium and Titanium Chelating Alkoxide Complexes," Journal of American Chemical Society, Vol. 119, No. 31, 1997, pp. 7190-7196. doi:10.1021/ja970861g

[42] R. D. J. Froese, D. G. Musaev, T. Matsubara and K. Morokuma, "Theoretical Studies of the Factors Controlling Insertion Barriers for Olefin Polymerization by the Titanium-Chelating Bridged Catalysts. A Search for More Active New Catalysts," Organometallics, Vol. 18, No. 3, 1999, pp. 373-379. doi:10.1021/om9809466

[43] Y. Kim, Y. Han, M. Y. Lee, S. W. Yoon, K. H. Choi, B. G. Song and Y. Do, "New Half-Metallocene Catalysts Generating Polyethylene with Bimodal Molecular Weight Distribution and Syndiotactic Polystyrene," Macromolecular Rapid Communication, Vol. 22, No. 8, 2001, pp. 573-578. doi:10.1002/1521-3927(20010501)22:8<573::AID-MAR C573>3.0.CO;2-S 